\title{
Do elderly NSCLC stage IV patients benefit from chemotherapy as well as younger? An analysis from clinical practice date
}

\author{
Regina Gironés, Pedro López, Rebeca Chulvi, Mamen Cañabate
}

Medical Oncology Unit, Lluís Alcanyís Hospital, 46800 Xàtiva, Spain.

Correspondence to: Dr. Regina Gironés, Medical Oncology Unit, Lluís Alcanyís Hospital, Crta Xàtiva a Silla km 2, 46800 Xàtiva, Valencia, Spain. E-mail: girones_reg@gva.es

How to cite this article: Gironés R, López P, Chulvi R, Cañabate M. Do elderly NSCLC stage IV patients benefit from chemotherapy as well as younger? An analysis from clinical practice date. J Cancer Metasta Treat 2016;2:379-87.

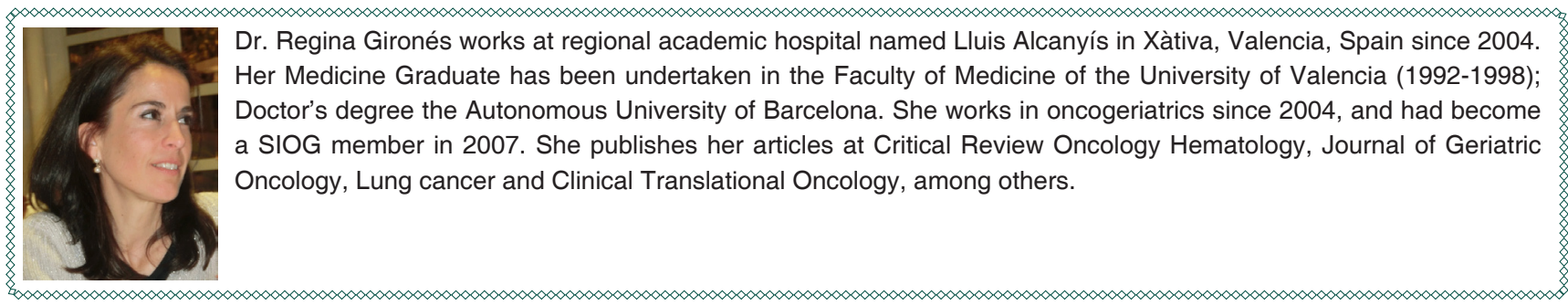

\section{Article history:}

Received: 21-04-2016

Accepted: 19-07-2016

Published: 30-09-2016

\section{Key words:}

Non-small cell lung cancer,

elderly,

chemotherapy,

overall survival,

smoking habits,

platinum-combinations

\begin{abstract}
Aim: The aim of this study was to evaluate the efficacy of treatment related to age in metastatic non-small cell lung cancer (NSCLC). We compared young and elders (> 70) in the setting of a regional Spanish hospital. We hypothesized that elder benefit as much as younger patients from chemotherapy in stage IV NSCLC. The study was limited to performance status 0-2. Methods: Clinical and demographic characteristics were reviewed form medical records. Type of treatment was collected and compared, as well as benefit from treatment, in terms of overall survival. Results: 322 patients (162 young, 160 aged) Elderly patients received less active treatment $(63 \%$ vs. $86 \%, P=0.001)$. Elderly received less chemotherapy, less cisplatin-doublets, more carboplatin-combinations and monotherapy $(P=0.035)$. The benefits of treatment were similar, regardless of age. Smoking status demonstrated a prognosis impact for elder patients treated with chemotherapy. Those who remained active smokers had a lower overall survival in the aged group. In a multivariate analysis, the Eastern Cooperative Oncology Group, active treatment and non-smoking history were favorable prognostic factors for elder patients. Smoking had not impact on young patients. Conclusion: Elderly patients were undertreated in clinical practice. Treatment showed similar overall survival despite of age. The impact of smoking seems to be more significant in the elderly population.
\end{abstract}

cC (7) (2) This is an open access article distributed under the terms of the Creative Commons Attributioncc) NC SA NonCommercial-ShareAlike 3.0 License, which allows others to remix, tweak, and build upon the work non-commercially, as long as the author is credited and the new creations are licensed under the identical terms.

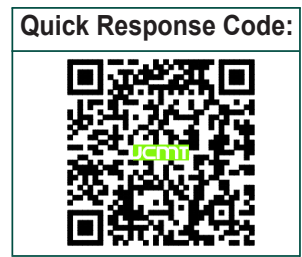

For reprints contact: service@oaepublish.com 


\section{INTRODUCTION}

Lung cancer remains the most frequent cause of cancer-related death worldwide. ${ }^{[1]}$ Elderly patients make up a substantial proportion of non-small cell lung cancer (NSCLC) patients and their numbers are expected to increase. ${ }^{[2]}$ They've been significantly underrepresented in clinical trials, making it difficult to extrapolate clinical trial data. ${ }^{[3]}$ Despite the clear benefits to survival, most elderly patients with advanced NSCLC are under-treated or do not receive chemotherapy. ${ }^{[4,5]}$ In general there is an expectation that elderly patients have poor tolerance to treatment. ${ }^{[6]}$ Physicians may be reluctant to offer treatment known to provoke troublesome side effects due to the unwarranted assumption that elderly patients do not benefit from cytotoxic therapy. ${ }^{[7,8]}$ Consequently, elderly patients are frequently under-treated, and only one quarter of elderly patients (> 65 years) with advanced NSCLC are reported to receive palliative chemotherapy. ${ }^{[4,9]}$ Advanced age has been a prevalent reason for not administering treatment, contrary to established guidelines. ${ }^{[10-12]}$

Platinum-based doublet chemotherapy is considered to be standard of care for elderly patients with an Eastern Cooperative Oncology Group Performance Status (ECOG PS) score of $0-1 . .^{[13-14]}$ The association of a platinum compound with a third-generation agent improves survival, ${ }^{[15-16]}$ and seems to be the most effective therapeutic choice in such cases. Recently, several elderly-specific trials showed that chemotherapy is effective and feasible for elderly patients with NSCLC. ${ }^{[17-21]}$ National Comprehensive Cancer Network guidelines recommend platinumdoublet chemotherapy in patients with good performance status regardless of age..$^{[22]}$ The European Organization for Research and Treatment of Cancer/ International Society for Geriatric Oncology also recommend the use of carboplatin-based doublets in fit elderly patients and single-agent treatment for less fit patients. ${ }^{[12]}$ Despite recent developments in treatment recommendations for elderly patients, little is known about use of these in clinical practice, and very limited data are available for elderly patients outside of clinical trials. Limited data exist regarding realworld treatment patterns and outcomes with respect to patients with metastatic NSCLC treated at Spanish regional hospitals.

We hypothesized that elder benefit as younger patients from chemotherapy in stage IV NSCLC. Therefore, in this study, we aimed to evaluate the proportion of elderly advanced NSCLC patients attended at clinical practice who are candidates for standard systemic chemotherapy, the actual proportion of patients who receive chemotherapy, the actual treatment they received and clinical outcome in these patients.

\section{METHODS}

We collected on a prospective manner of all patients with advanced NSCLC (stage IV) seen at the Regional Medical Oncology Unit form the Hospital Lluis Alcanyis, Xàtiva since January 2004, creating a data base register. Patients collected for this analysis accomplished the following conditions: histological or cytological confirmation of NSCLC (although we accepted radiological diagnosis without histological confirmation) in stage IIIB (pleural effusion, prior TNM stage), or stage IV of the disease. Outpatient and those are suitable for treatment (PS 0-2). We collected data on baseline demographics, clinical characteristics and a detailed treatment history. Our study period covers January 2004 until December 2014. Tumor histology was classified on the basis of the 2004 WHO classification. ${ }^{[23]}$ Patients were classified respect to smoking habits into 3 groups: never smoker, active smoker and ex-smoker (if they had quit smoking a year or more prior to diagnosis). Data on drugsensitive epidermal growth factor receptor (EGFR) mutations was collected, since June 12010 using peptide nucleic acid-locked nucleic acid polymerase chain reaction clamp-based testing. When testing was not performed the data was recorded as "unknown". Anaplastic lymphoma kinase (ALK) translocations have been determined via fluorescence in situ hybridization since June 2012. Studies of K-RAS mutation are not performed as part of standard care. For surviving patients, final follow up was recorded on 15th December 2014. Survival time was calculated from the time of diagnosis until death or final follow up.

Statistical evaluation was performed using SPSS version 20.0 software; unpaired Student's $t$-test, Chisquared, and Fischer exact test were used according to data type. Statistical significance was defined as $P<$ 0.05 ; variables were considered to be independent for the statistical analysis; continuous data was expressed as mean \pm standard error. Statistical analyses of categorical variables were performed using Pearson's Chi-square test or Fisher's exact test as appropriate. Survival analysis was performed using the KaplanMeier method, and groups were compared using the log-rank test. Univariate and multivariate analyses were performed using the Cox proportional hazard regression analysis.

The institution's ethical review board approved the data base on 2004. Also it approved the review of 
Table 1: Clinical characteristics of the patients; comparison between age groups

\begin{tabular}{|c|c|c|c|}
\hline & $\begin{array}{c}\text { Group 1: } \\
<70 \text { years old } \\
162(50.3 \%)\end{array}$ & $\begin{array}{c}\text { Group 2: } \\
>70 \text { years old } \\
160(49.7 \%)\end{array}$ & $P$ \\
\hline $\begin{array}{l}\text { Age, years } \\
\text { Mean, range }\end{array}$ & $59(34-69)$ & $76(70-91)$ & \\
\hline $\begin{array}{l}\text { Gender } \\
\text { Men } \\
\text { Women }\end{array}$ & $\begin{array}{l}139(87 \%) \\
23(13 \%)\end{array}$ & $\begin{array}{c}142(88 \%) \\
18(12 \%)\end{array}$ & $P=0.266$ \\
\hline $\begin{array}{l}\text { PS 0-1 } \\
\text { PS } 2\end{array}$ & $\begin{array}{c}136(84 \%) \\
26(16 \%)\end{array}$ & $\begin{array}{l}98(61 \%) \\
62(39 \%)\end{array}$ & $P=0.00001$ \\
\hline $\begin{array}{l}\text { Histology, } n(\%) \\
\text { Unconfirmed } \\
\text { Squamous } \\
\text { Adenocarcinoma } \\
\text { Large cell carcinoma } \\
\text { Untyped carcinoma }\end{array}$ & $\begin{array}{c}4(2 \%) \\
55(34 \%) \\
88(55 \%) \\
10(6 \%) \\
5(3 \%)\end{array}$ & $\begin{array}{c}10(6 \%) \\
70(44 \%) \\
59(37 \%) \\
15(10 \%) \\
6(3 \%)\end{array}$ & $\begin{array}{c}P=0.025 \\
P=0.023 \\
P=0.0322 \\
P=0.53 \\
P=0.6\end{array}$ \\
\hline $\begin{array}{l}\text { Smoking habits: } \\
\text { Never smoker } \\
\text { Active smoker } \\
\text { Ex-smoker }\end{array}$ & $\begin{array}{c}13(8 \%) \\
112(69 \%) \\
37(23 \%)\end{array}$ & $\begin{array}{l}28(18 \%) \\
33(20 \%) \\
99(62 \%)\end{array}$ & $P=0.0001$ \\
\hline $\begin{array}{l}\text { EGFR status } \\
\text { Unknown } \\
\text { Mutated } \\
\text { Wild-type }\end{array}$ & $\begin{array}{c}51(31 \%) \\
12(7 \%) \\
99(62 \%)\end{array}$ & $\begin{array}{l}65(40 \%) \\
17(11 \%) \\
78(49 \%)\end{array}$ & $P=0.0001$ \\
\hline $\begin{array}{l}\text { EGFR status in adenocarcinoma (147) } \\
\text { Unknown } \\
\text { Mutated } \\
\text { Wild-type }\end{array}$ & $\begin{array}{c}(88) \\
8(9 \%) \\
12(14 \%) \\
68(77 \%)\end{array}$ & $\begin{array}{c}(59) \\
8(13 \%) \\
17(29 \%) \\
34(58 \%)\end{array}$ & $P=0.0005$ \\
\hline
\end{tabular}

EGFR: epidermal growth factor receptor; PS: performance status

the records. Informed consent was obtained from all individual before inclusion in the data base.

\section{RESULTS}

From January 2004 until December 2014, 322 patients (162 patients in Group 1 and 160 patients in Group 2) were included in the analysis. Clinical characteristics and comparison between age groups are shown in Table 1 . In the elderly group, $30 \%$ were octogenarians. More elderly patients had a PS of $2(39 \%$ vs. $16 \%$, $P=0.00001$ ); and were derived without histological confirmation ( $6 \%$ vs. $2 \%, P=0.025)$. Squamous cell carcinomas predominate on the elderly $(44 \%$ vs. $34 \%, P=0.023$ ). The majority of patients had had an smoking history $(92 \%$ of younger patients vs. $82 \%$ of the elderly, $P=0.001)$. Most of the elderly patients were ex-smokers $(62 \%)$ while the younger patients tended to be active smokers $(69 \%)$. Smoking habit was related to squamous histology in the elderly group. Younger smokers developed both squamous cell and adenocarcinoma meanwhile, in the elderly group, we found a link between the following characteristics: female gender, adenocarcinoma, no history of smoking and EGFR-mutation ( $P=0.00001) ; 99 \%$ of aged women were never smokers and there were no elderly women with squamous histology. Smoking status was unrelated to PS.
No patient in our series had ALK rearrangement (analysis started on June 2012). In terms of EGFR mutations, 116 patients had unknown status (patients diagnosed prior to 2010). In both groups all EGFRmutations were found in adenocarcinoma $(P=0.00001)$. No mutations were found in women smokers; never smoking predicted EGFR status in women in both age groups, while in men this only occurred in the elderly $(P=0.0001)$. In younger men, smoking habit did not predict mutation status [Figure 1].

There was a higher percentage of EGFR-mutations in the elderly group. In the global series, $25 \%$ of adenocarcinoma were found to be mutated; $13 \%$ in younger group, $28 \%$ in elderly group $(P=0.01)$.

Treatment data: Table 2 shows differences in patterns of treatment. Patients without histological diagnosis didn't receive treatment in either age group. Of the 102 elderly patients who received first-line treatment, $71(70 \%)$ were treated with chemotherapy, 17 (16\%) with EGFR TKI and 14 (14\%) with radiotherapy. Elderly patients had received less active treatment $(P=0.0001)$. $P S$ influenced whether treatment was administered or not in both groups $(P=0.0001)$. Performance status was an independent predictor, as patients with PS of 2 did not receive chemotherapy in either group. The same proportion of patients with a PS of 2 received 
Elderly EGFR mutated

- Men never smoker - -Women never smoker Men smoker : Men exsmoker

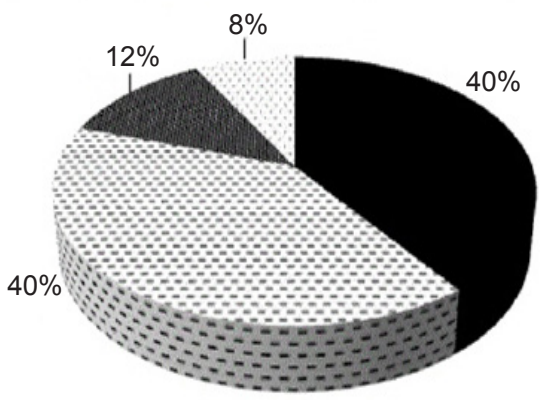

Figure 1: EGFR mutation and smoking habit in elderly patients. EGFR: epidermal growth factor receptor

palliative brain radiation in the two groups (3 and 6; $10 \%)$. Elderly patients received less chemotherapy $(P$ $=0.0001)$ and were more likely to receive palliative radiation as sole treatment $(81 \%$ vs. $5 \%)$. In the younger group, of the 124 patients with PS 0-1 suitable for chemotherapy (excluding 12 patients with EGFR mutation); 118 (95\%) were treated with chemotherapy. In the elderly group, 71 of 98 patients $(72 \%)$ suitable for chemotherapy received this treatment. More elderly patients with good $\mathrm{PS}$ received palliative radiotherapy as sole treatment ( $4 \%$ vs. $8 \%, P=0.0001)$. Overall, of the 189 patients that received chemotherapy $(58.6 \%$ of the global series), $62.5 \%$ were in the younger group vs. $37.5 \%$ who were elderly $(P=0.0001)$. In terms of chemotherapy, the elderly received more carboplatin combinations (34\% vs. $60 \%$ ), monotherapy (6\% vs. $30 \%$ ) and were less likely to receive bevacizumab combinations $(2 \%$ vs. $18 \%)(P=0.035)$. All patients with EGFR mutation received first line EGFR TKI. Only one patient with an EGFR mutation in the elderly group had PS 2.

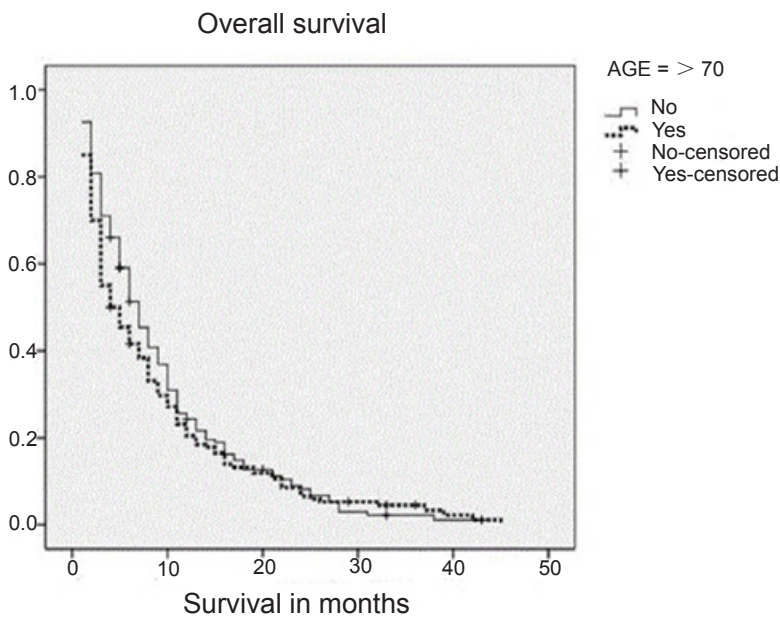

Figure 2: Comparison on overall survival between age groups
Table 2: Treatment date and comparison between age groups

\begin{tabular}{|c|c|c|c|}
\hline . & $\begin{array}{l}\text { Young } \\
(162)\end{array}$ & $\begin{array}{l}\text { Elders } \\
(160)\end{array}$ & $\boldsymbol{P}$ \\
\hline \multicolumn{4}{|l|}{ Treatment } \\
\hline Yes & $139(86 \%)$ & $102(63 \%)$ & \\
\hline No & $23(14 \%)$ & $57(37 \%)$ & $P=0.0001$ \\
\hline Treatment and PS & & & $P=0.52$ \\
\hline PS 0-1 & 136 & 98 & \\
\hline Yes & $136(100 \%)$ & 95 (97\%) & \\
\hline No & 0 & $3(3 \%)$ & \\
\hline PS 2 & 26 & 61 & \\
\hline Yes & $3(12 \%)$ & $7(11 \%)$ & \\
\hline No & $23(88 \%)$ & $54(89 \%)$ & \\
\hline \multicolumn{4}{|l|}{ Kind of treatment and PS } \\
\hline PS $0-1$ & 136 & 95 & \\
\hline Chemotherapy & $118(86 \%)$ & $71(74 \%)$ & \\
\hline Radiotherapy & $6(4 \%)$ & $8(8 \%)$ & \\
\hline EGFR-TKI & $12(10 \%)$ & $16(18 \%)$ & $P=0.0001$ \\
\hline PS 2 & 3 & 7 & \\
\hline EGFR-TKI & 0 & $1(15 \%)$ & \\
\hline Radiotherapy & $3(100 \%)$ & $6(85 \%)$ & \\
\hline Kind of chemotherapy & 118 & & $P=0.035$ \\
\hline Cisplatin-combination & $48(41 \%)$ & $4(5 \%)$ & \\
\hline Carboplatin-combination & $41(34 \%)$ & $42(60 \%)$ & \\
\hline Monotherapy & $8(7 \%)$ & $21(30 \%)$ & \\
\hline Bevacizumab combination & $21(18 \%)$ & $2(2 \%)$ & \\
\hline
\end{tabular}

EGFR: epidermal growth factor receptor; TKI: tyrosine kinase inhibitor; PS: performance status

For the global series, overall survival was 8.979 months [95\% confidence interval $(\mathrm{Cl}) 7.949-10.08]$ and there was no difference between age groups (9.42 vs. 8.48 months; $P=0.0238$ ) [Figure 2].

According to the univariate analysis using Cox proportional hazard regression analysis, the following factors were related to better survival: female gender, ECOG PS 0-1, adenocarcinoma histology, no history of smoking, presence of EGFR mutation, administration of treatment, chemotherapy and EGFR-TKI therapy.
$P S=P S 0-1$

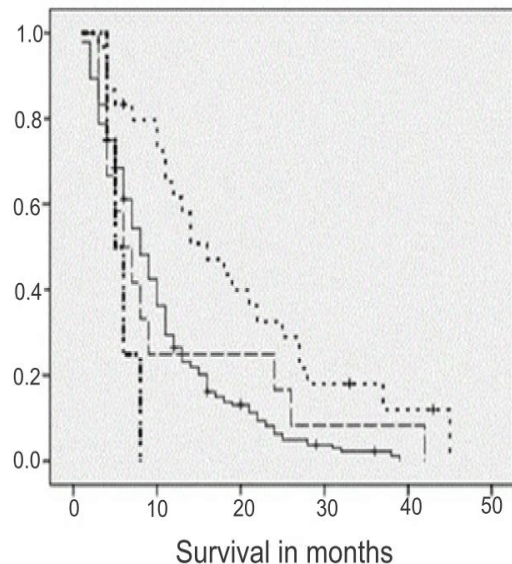

Type of treatment

Chemotherapy

$\therefore$ EGFR TKI

- Radiotherapy

."' No chemotherapy

+ Chemotherapy-censored

+ EGFR TKI-censored
Figure 3: Comparison: treated versus untreated young patients EGFR: epidermal growth factor receptor; TKI: tyrosine kinase inhibitor; PS: performance status 
Table 3: Multivariate analyses

\begin{tabular}{|c|c|c|c|}
\hline & Young (162) & Elders (160) & $P$ \\
\hline Age & $9.4(8.0-10.7)$ & $8.4(6.9-10.00)$ & 0.238 \\
\hline $\begin{array}{l}\text { Male } \\
\text { Female }\end{array}$ & $\begin{array}{c}\mathrm{N}: \text { 139: SG 8-8 (7.4-10.2) } \\
\mathrm{N}: 23 . \mathrm{SG}: 12.8(8.8-16.9) \\
P=0.069\end{array}$ & $\begin{array}{l}\mathrm{N}: 142 . \text { SG: } 7.9(6.4-9.4) \\
\mathrm{N}: 18 . \mathrm{SG}: 12(6.7-17.3) \\
P=0.014\end{array}$ & 0.263 \\
\hline $\begin{array}{l}\text { PS } 0-1 \\
\text { PS } 2\end{array}$ & $\begin{array}{c}\mathrm{N}: 136 \text { SG: } 10.7(9.2-12.2) \\
\mathrm{N}: 26 . \mathrm{SG}: 2.5(1.3-3.7) \\
P=0.0001\end{array}$ & $\begin{array}{c}\text { N: 98. SG: } 12.3(10.2-14.5) \\
\mathrm{N}: 62 . \mathrm{SG}: 2.3(1.9-2.7) \\
P=0.0001\end{array}$ & 0.259 \\
\hline $\begin{array}{l}\text { Never smoker } \\
\text { Smoker } \\
\text { Ex-smoker }\end{array}$ & $\begin{array}{c}\text { N: 13. SG: } 15.7(10.4-21.1) \\
\text { N: } 112 \text {. SG: } 8.7(7.2-10.2) \\
\text { N: 37. SG: } 8.8(6.1-11.5) P=0.041\end{array}$ & $\begin{array}{c}\text { N: 28. SG: } 13.3(8-18.7) \\
\text { N: 33. SG: } 5.4(3.5-7.3) \\
\text { N: 99. SG: } 8.2(6.4-10) P=0.001\end{array}$ & 0.098 \\
\hline $\begin{array}{l}\text { EGFR unknown } \\
\text { EGFR mutated } \\
\text { EGFR wild type }\end{array}$ & $\begin{array}{c}\text { N: 25. SG: } 9.9(6.8-12.9) \\
\text { N: 12. SG: } 21.0(13.7-28.3) \\
\text { N: 125. SG: } 8.1(6.8-9.4) P=0.002\end{array}$ & $\begin{array}{r}\text { N: 33. SG: } 8.1(5.6-10.6) \\
\text { N: 17. SG: } 16.8(10.2-23.3) \\
\text { N: 110. SG: } 7.3(10.2-23.3) P=0.0001\end{array}$ & 0.112 \\
\hline $\begin{array}{l}\text { Squamous } \\
\text { Adenocarcinoma }\end{array}$ & $\begin{array}{c}\text { N: 55. SG: } 7.6(5.8-9.3) \\
\text { N: 88. SG: } 10.9(8.8-13) \\
P=0.018\end{array}$ & $\begin{array}{c}\text { N: 70.SG: } 7.5(5.6-9.4) \\
\text { N: 59. SG: } 10.1(7.1-13.1) P=0.002\end{array}$ & 0.612 \\
\hline $\begin{array}{l}\text { Treated } \\
\text { No treated }\end{array}$ & $\begin{array}{l}\text { N: 139. SG: } 10.5(9-12) \\
\text { N: 23. SG: } 2.5(1.1-3.8) \\
P=0.00001\end{array}$ & $\begin{array}{l}\text { N: 102. SG: } 11.8(9.7-13.9) \\
\text { N: 57. SG: } 2.5(2-3) P=0.00001\end{array}$ & 0.19 \\
\hline $\begin{array}{l}\text { Chemotherapy } \\
\text { Radiotherapy } \\
\text { EGFR TKI }\end{array}$ & $\begin{array}{c}\text { N: 117. SG: } 18.0(11.9-24) \\
\text { N: } 8 . \text { SG: } 3.0(1.89-4.1)) \\
\text { N: 13. SG:19.7 (12.5-26.9) } \\
P=0.0001\end{array}$ & $\begin{array}{c}\text { N: } 71 . \text { SG:10.6 (8.5-12.8) } \\
\text { N: } 13 . \text { SG: } 3.6(2.4-4.7) \\
\text { N: 18. SG: } 17.8(11.4-24.2) P=0.0001\end{array}$ & 0.365 \\
\hline $\begin{array}{l}\text { Combined chemotherapy } \\
\text { Monotherapy } \\
\text { Bevacizumab }\end{array}$ & $\begin{array}{c}\text { N: 89. SG: } 9.2(8.2-13.1) \\
\text { N: 8. SG: } 5.4(3.3-7.4) \\
\text { N: 21. SG: } 14.5(10.3-18.6) P=0.024\end{array}$ & $\begin{array}{c}\text { N: 48. SG: } 10.7(8.2-13.1) \\
\text { N: 21. SG: } 10.1(6.3-13.9) \\
\text { N: } 2 \text { SG: } 19.0(12-42) P=0.248\end{array}$ & \\
\hline
\end{tabular}

EGFR: epidermal growth factor receptor; TKI: tyrosine kinase inhibitor; PS: performance status; SG: study group

Forfemalepatients, neversmokingandadenocarcinoma histology were related to EGFR-mutation and EGFRTKI; only EGFR-mutation remained significant in multivariate analysis for overall survival [Table 3].

When we excluded these confounding factors, PS 0-1 and systemic chemotherapy were independently associated with better survival in both groups.

There was a clear benefit associated with administration of some treatment in both groups (10.5 vs. 2.5 months in the younger group, $P=0.0000$ and 11.8 vs. 2.5 months in the elderly group, $P=0.000$ ) [Figures 3 and 4]. For those patients suitable for treatment (PS $0-1$ ), radiotherapy, chemotherapy and EGFR treatment when appropriate were also found to provide benefits [Figure 5]. No impact on overall survival was found with respect to treatment for patients with a PS of 2 (3 vs. 2.6 vs. 2.3 months; radiotherapy vs. chemotherapy vs. EGFR treatment respectively).

Elderly patients were found to benefit slightly from chemotherapy (9.9 vs. 10.6 months; no chemotherapy vs. chemotherapy respectively, $P=0.42$ ). In terms of

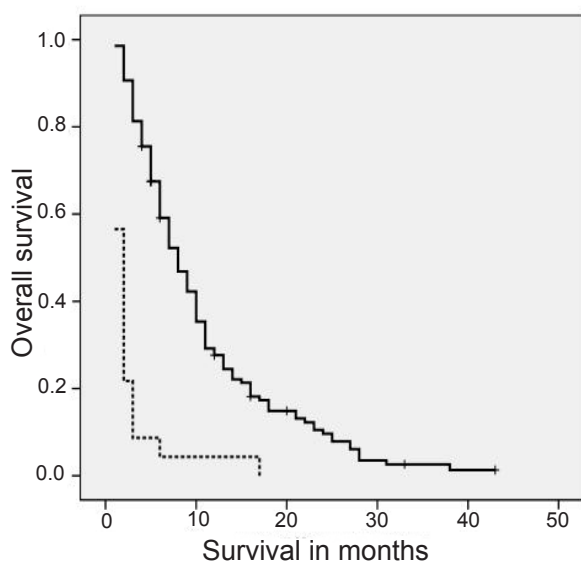

Figure 4: Comparison: treated versus untreated elder patients
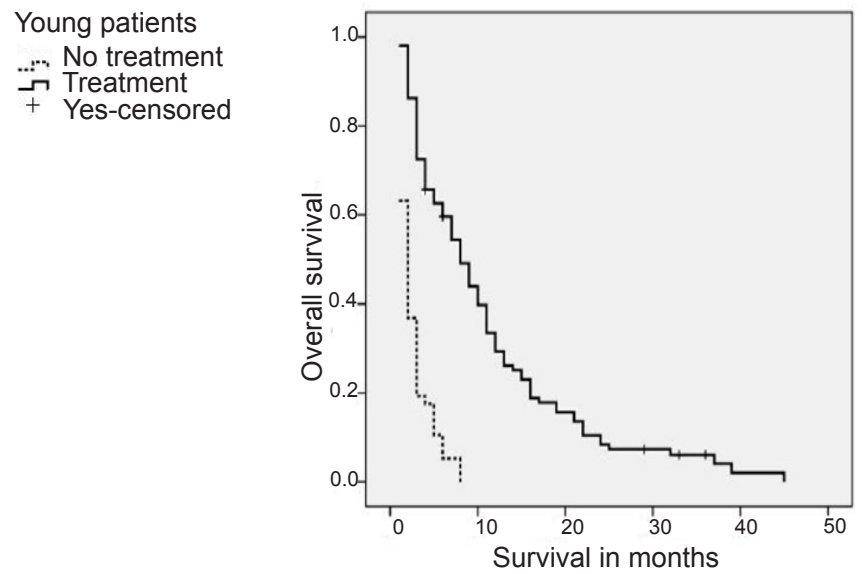

Elderly patients

+ Yes-censored

$\rightarrow$ No treatment

$\sim$ Treatment

Figure 5: Benefit of treatment in terms on overall survival for elderly patients 


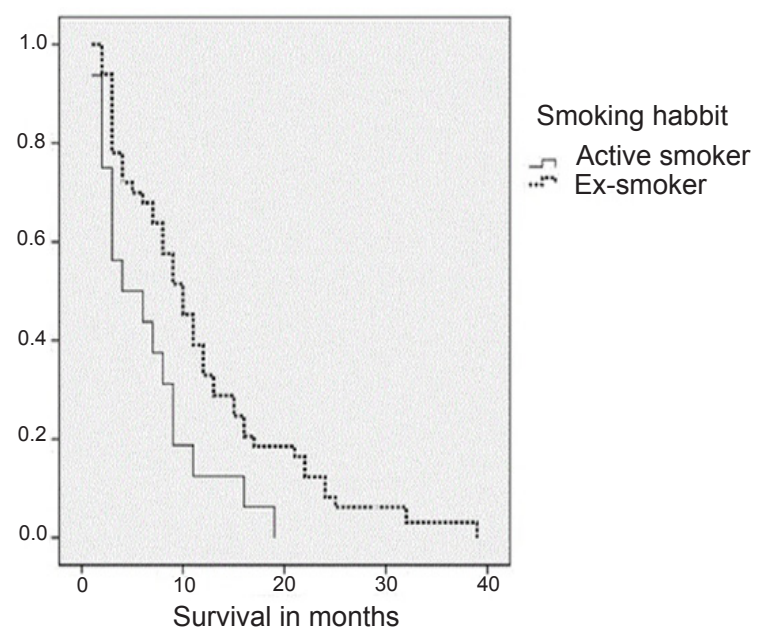

Figure 6: Differences in overall survival by smoking status in elderly patients treated with chemotherapy

platinum-combinations vs. monotherapy, the same benefit was found for younger versus elderly patients $(P=0.14)$. Platinum-combinations were found to be more effective in younger patients (9.5 vs. 5.7 months; platinum vs. non-platinum combinations respectively), but no differences were found in the elderly group (10.5 vs. 10.2 months; combination vs. monotherapy). Few patients were treated with bevacizumab and we are therefore unable to draw conclusions. No differences in survival were found with respect to distinct platinum combinations.

Smoking habit had impact on overall survival in elderly patients that received chemotherapy $(P=0.006)$ [Figure 6]. Median overall survival for active smokers during chemotherapy treatment was 6.5 (95\% Cl 3.99.1) vs. 12.1 months (95\% Cl 9.5-14.7), $P=0.011$ for those who had quit smoking. In addition, smoking had an impact on the outcomes of patients who received combination therapy in the elderly group; smokers treated with platinum-combination had median overall survival of 6.9 months $(95 \% \mathrm{Cl}$ 4.1-9.6) vs. 12.7 months in ex-smokers $(95 \% \mathrm{Cl}$ 9.4-15.9. Median overall survival for patients receiving monotherapy in the elderly group was 6.8 months for active smokers (95\% Cl 3.2-13.1) vs. 10.8 months in ex-smokers (95\% $\mathrm{Cl}$ 6.4-15.1) $(P=0.014)$. The relationship between smoking status and chemotherapy was not significant in the younger group.

\section{DISCUSSION}

In this study, we analyzed all elderly patients with advanced NSCLC who visited our outpatient hospital over a 10-year period, and found that $64 \%(n=102)$ received active treatment. The elderly patients treated benefit in a similar way that younger counterparts.
Smoking had an important impact on elderly patients treated.

Elderly patients tended to have poorer PS. All of the elderly women except one were never smokers. With the increasing number of female smokers, it is uncertain whether in the future we will see greater numbers of elderly women smokers. ${ }^{[24-27]}$ Most probably, due to the high sensitivity of women to tobacco carcinogens, the tendency will be towards an increase of younger female lung cancer patients. ${ }^{[28]}$ In any case, never smoker status was significantly related to EGFR-mutation in elderly and younger women. A higher prevalence of EGFR mutations in the elderly has already been described, ${ }^{[29]}$ and, as in our series, older age at diagnosis has been reported to be an independent predictor of EGFR mutations in female never-smokers with adenocarcinoma. ${ }^{\left[{ }^{30]}\right.}$ In this study, in males never smokers, smoking habit was related to EGFR mutation in the elderly group only; it was not a predictor of EGFR status in the younger group. Smoking was related to histology in the elderly; squamous cell lung carcinoma was the main histology in this group. Adenocarcinoma related to smoking was more predominant in the younger group. It should be taken into account that the elderly patients were mostly ex-smokers. The high incidence of smoking history in the elderly has already been described. ${ }^{[31]}$

Most elderly patients with metastatic NSCLC do not receive chemotherapy, as database analyses have shown. ${ }^{[4]}$ In our series, elderly patients were less likely to receive chemotherapy than younger patients; however on analysis of those elderly patients suitable for chemotherapy, almost $85 \%$ received chemotherapy. This is a probably a higher rate of treatment than reported in published data. ${ }^{[34]}$ For example, one analysis performed by SEER-Medicare, ${ }^{[4]}$ which considered elderly patients as those > 66 years, showed that only $25.8 \%$ received first-line chemotherapy. In that study, multivariate analyses indicated that with increasing age, comorbidity and poor PS, treatment with any chemotherapy and platinum-based doublet regimens is less likely to be used. In our series, the elderly patients were older than those in the SEER analysis (> 70). From a total of 160 elderly patients, $71(44.3 \%)$ received chemotherapy. This is a higher figure than reported in other studies. Platinum-doublet chemotherapy regimens have been shown to extend survival in fit patients with advanced non-small-cell lung cancer. ${ }^{[4]}$ At our study, both, cytotoxic chemotherapy and EGFR TKI treatments are feasible and prolong survival when comparisons are made with patients who do not receive chemotherapy in both groups. It seems that the benefit of treatment of elderly patients 
is similar (indeed a little better) to those obtained by their younger counterparts.

Doublet platinum-based chemotherapy regimens are the standard of care for both adult and elderly fit advanced NSCLC patients, with good tolerance and only minor effects on quality of life (QoL). ${ }^{[32,33]}$ In our study, a high percentage of elderly patients with PS 0-1 suitable for chemotherapy did in fact receive chemotherapy. Since 2006 we have used geriatric assessments to determine suitability for treatment. ${ }^{[34,35]}$ All young patients with good PS were treated; but there were no differences in overall survival for those elderly. Are elderly patients undertreated? Or are younger patients overtreated?

The elderly were less likely to receive cisplatincombinations and more likely to receive monotherapy. Surprisingly we did not find any differences when comparing platinum-combinations to monotherapy. Monotherapy has been for several years the recommended palliative treatment for elderly patients with advanced NSCLC. ${ }^{[36]}$ Factors that influence whether a patient receives a platinum-doublet or single-agent are unclear in the elderly. Over the period of study we have found a tendency to prescribe monotherapy, probably due to doubts about the benefit of platinum-combination until recently. Probably, these elder patients were more carefully selected, and we do not know whether they would have benefited from a platinum-combination. Other authors found that platinum-doublet chemotherapy provides greater benefits than single agents in the elderly. ${ }^{[4]}$

It is difficult to make conclusions in the sense that this is not a randomized study. Bevacizumab has not been specifically studied in older patients. ${ }^{[37]}$ As few elderly patients were treated with bevacizumab we are unable to draw conclusions. Probably the two patients suitable for first line bevacizumab were carefully selected. At present we are exploring bevacizumab in elderly patients selected using geriatric assessment (ClinicalTrials.gov identifier: NCT01980472). For chemotherapy combinations (vinorelbine, gemcitabine, paclitaxel, pemetrexed, docetaxel) we did not find any differences in elderly patients, which leads us to draw the conclusion that, as in younger patients, the benefits of chemotherapy have reached a plateau. ${ }^{[6,38]}$

Our results indicate that chemotherapy treatment is strongly associated with greater survival. Furthermore, the magnitude of this benefit is comparable with that seen in clinical trials, or even more so. The closeness of these estimates suggests that with adequate adjustments for patients' characteristics, observational studies can provide very useful information on the effectiveness of treatment.

The same prognostic factors were found for in the elder and younger patients; PS 0-1, active treatment, never smoker and EGFR mutation, regardless of age. For elderly patients, smoking has impact on benefit from chemotherapy, as ex-smokers benefit more from both combination and monotherapy.

Our analysis raises several questions that deserve future study. In particular, we have noted that despite gains in treatment rates during the study period, overall survival remains poor and smoking continues to be a major factor in determinant treatment outcomes, although only for the elderly. Our survival results indicate that appropriate patients, regardless of age, can benefit from aggressive treatment. Additional work on smoking is need to further elucidate the role of smoking on age and treatment outcomes.

Our study has several limitations. First, this analysis was conducted in a single center, so we cannot extrapolate our results the overall population with lung cancer. Secondly, we have an important selection bias, as we only collected data on ambulatory patients. However, these are the patients that benefit most from chemotherapy. Thirdly, some variables have not been collected (median number of chemotherapy cycles, chemotherapy lines, and progression-free survival). Also, EGFR mutation test and ALK rearrangement tests were not fully performed in most patients.

However, this study also has strengths. All data was collected from the same oncology unit, and patients were all attended by the same oncologist (Dr. Gironés). Possible confounding factors for treatment (physician bias) have been prevented. [39] The number of cases was relatively high. To date, most studies of elderly lung cancer patients have been from subgroup analysis of phase III studies or were specific studies for elderly patients with fewer patients. Studies with high numbers of patients were retrospective. ${ }^{[6,38]}$

In conclusion, patients do benefit from aggressive chemotherapy regardless of theirage. Ourobservational data provide an opportunity to understand the effects of treatment when applied in routine practice and assess whether outcomes are comparable to those obtained in clinical trials. Approximately $45 \%$ of the elderly patients with advanced NSCLC seen at our routine clinical practice received active treatment with chemotherapy, and this prolonged survival in a similar way to in their younger counterparts. The most significant advances in median overall survival have been in cases of lung cancer unrelated to smoking (EGFR-mutations). Unfortunately, smoking remains the main cause of 
lung cancer in elderly patients. Efforts to prevent the initiation of the smoking habit and also to quit smoking should be made, regardless of age.

\section{Financial support and sponsorship} Nil.

\section{Conflicts of interest}

There are no conflicts of interest.

\section{Patient consent Obtained.}

\section{Ethics approval}

Ethics approval was obtained prior to the commencement of the study.

\section{REFERENCES}

1. Alberg AJ, Brock MV, Ford JG, Samet JM, Spivack SD. Epidemiology of lung cancer: diagnosis and management of lung cancer, 3rd ed: American College of Chest Physicians evidence-based clinical practice guidelines. Chest 2013;143:e1S-29S.

2. Hurria A, Browner IS, Cohen HJ, Denlinger CS, deShazo M, Extermann M, Ganti AK, Holland JC, Holmes HM, Karlekar MB, Keating NL, McKoy J, Medeiros BC, Mrozek E, O'Connor T, Petersdorf SH, Rugo HS, Silliman RA, Tew WP, Walter LC, Weir AB 3rd, Wildes T. Senior adult oncology. J Natl Compr Canc Netw 2012;10:162-209.

3. Sacher AG, Le LW, Leighl NB, Coate LE. Elderly patients with advanced NSCLC in phase III clinical trials: are the elderly excluded from practice-changing trials in advanced NSCLC? $J$ Thorac Oncol 2013;8:366-8.

4. Davidoff AJ, Tang M, Seal B, Edelman MJ. Chemotherapy and survival benefit in elderly patients with advanced non-small-cell lung cancer. J Clin Oncol 2010;28:2191-7.

5. Beckett P, Callister M, Tata LJ, Harrison R, Peake MD, Stanley R, Woolhouse I, Slade M, Hubbard RB. Clinical management of older people with non-small cell lung cancer in England. Thorax 2012;67:836-9.

6. Sim SH, Kim YJ, Kim SH, Keam B, Kim TM, Lee SH, Kim DW, Heo DS, Lee JS. Current status of chemotherapy use and clinical outcome in octogenarians with advanced non-small cell lung cancer. $J$ Cancer Res Clin Oncol 2015;14:1073-81.

7. Firat S, Pleister A, Byhardt RW, Gore E. Age is independent of comorbidity influencing patient selection for combined modality therapy for treatment of stage III nonsmall cell lung cancer (NSCLC). Am J Clin Oncol 2006; 29:252-7.

8. Wisnivesky JP, Strauss GM. Treating elderly patients with stage III NSCLC. Lancet Oncol 2012;13:650-1.

9. Wang S, Wong ML, Hamilton N, Davoren JB, Jahan TM, Walter LC. Impact of age and comorbidity on non-small-cell lung cancer treatment in older veterans. J Clin Oncol 2012;30:1447-55.

10. Blanco JAG, Toste IS, Alvarez RF, Cuadrado GR, Gonzalvez AM, Martín IJG. Age, comorbidity, treatment decision and prognosis in lung cancer. Age Ageing 2008;37:715-8.

11. de Rijke JM, Schouten LJ, Velde ten GPM, Wanders SL, Bollen EC, Lalisang RI, van Dijck JA, Kramer GW, van den Brandt PA. Influence of age, comorbidity and performance status on the choice of treatment for patients with non-smallcell lung cancer; results of a populationbased study. Lung Cancer 2004;46:233-45.
12. Pallis AG, Gridelli C, Wedding U, Faivre-Finn C, Veronesi G, Jaklitsch M, Luciani A, O'Brien M. Management of elderly patients with NSCLC; updated expert's opinion paper: EORTC elderly task force, Lung Cancer Group and International Society for Geriatric Oncology. Ann Oncol 2014;25:1270-83.

13. Weiss J, Langer C. Treatment of lung cancer in the elderly patient. Semin Respir Crit Care Med 2013;34:802-9.

14. D’Addario G, Pintilie M, Leighl NB, Feld R, Cerny T, Shepherd FA. Platinum-based versus non-platinum-based chemotherapy in advanced non-small-cell lung cancer: a meta-analysis of the published literature. J Clin Oncol 2005;23:2926-36.

15. Gridelli C, Gallo C, Shepherd FA, Illiano A, Piantedosi F, Robbiati SF, Manzione L, Barbera S, Frontini L, Veltri E, Findlay B, Cigolari S, Myers R, Ianniello GP, Gebbia V, Gasparini G, Fava S, Hirsh V, Bezjak A, Seymour L, Perrone F.Gemcitabine plus vinorelbine compared with cisplatin plus vinorelbine or cisplatin plus gemcitabine for advanced non-small-cell lung cancer: a phase III trial of the Italian GEMVIN Investigators and the National Cancer Institute of Canada Clinical Trials Group. J Clin Oncol 2003;21:3025-34.

16. Schiller JH, Harrington D, Belani CP, Langer C, Sandler A, Krook J, Zhu J, Johnson DH; Eastern Cooperative Oncology Group. Comparison of four chemotherapy regimens for advanced non-small cell lung cancer. N Engl J Med 2002;346:92-8.

17. Effects of vinorelbine on quality of life and survival of elderly patients with advanced non-small-cell lung cancer. The Elderly Lung Cancer Vinorelbine Italian Study Group. J Natl Cancer Inst 1999;91:66-72.

18. Frasci G, Lorusso V, Panza N, Comella P, Nicolella G, Bianco A, De Cataldis G, Iannelli A, Bilancia D, Belli M, Massidda B, Piantedosi F, Comella G, De Lena M. Gemcitabine plus vinorelbine versus vinorelbine alone in elderly patients with advanced non-small-cell lung cancer. J Clin Oncol 2000;18:2529-36.

19. Gridelli C, Perrone F, Gallo C, Cigolari S, Rossi A, Piantedosi F, Barbera S, Ferraù F, Piazza E, Rosetti F, Clerici M, Bertetto O, Robbiati SF, Frontini L, Sacco C, Castiglione F, Favaretto A, Novello S, Migliorino MR, Gasparini G, Galetta D, Iaffaioli RV, Gebbia V; MILES Investigators. Chemotherapy for elderly patients with advanced non-small-cell lung cancer: the Multicenter Italian Lung Cancer in the Elderly Study (MILES) phase III randomized trial. $J$ Natl Cancer Inst 2003;95:362-72.

20. Kudoh S, Takeda K, Nakagawa K, Takada M, Katakami N, Matsui K, Shinkai T, Sawa T, Goto I, Semba H, Seto T, Ando M, Satoh T, Yoshimura N, Negoro S, Fukuoka M. Phase III study of docetaxel compared with vinorelbine in elderly patients with advanced nonsmall-cell lung cancer: results of the West Japan Thoracic Oncology Group Trial (WJTOG 9904). J Clin Oncol 2006;24:3657-63.

21. Quoix E, Zalcman G, Oster JP, Westeel V, Pichon E, Lavolé A, Dauba J, Debieuvre D, Souquet PJ, Bigay-Game L, Dansin E, Poudenx M, Molinier O, Vaylet F, Moro-Sibilot D, Herman D, Bennouna J, Tredaniel J, Ducoloné A, Lebitasy MP, Baudrin L, Laporte S, Milleron B; Intergroupe Francophone de Cancérologie Thoracique. Intergroupe Francophone de Cancérologie Thoracique. Carboplatin and weekly paclitaxel doublet chemotherapy compared with monotherapy in elderly patients with advanced non-small-cell lung cancer: IFCT-0501 randomised, phase 3 trial. Lancet 2011;378:1079-88.

22. Ettinger DS, Akerley W, Borghaei H, Chang AC, Cheney RT, Chirieac LR, National comprehensive cancer network. Non-small cell lung cancer, version 2, 2013. J Natl Compr Canc Netw 2013;11:645-53.

23. Travis WD, Brambilla E, Müller-Hermelink HK, Harris CC. Pathology and genetics of tumours of the lung, pleura, thymus and heart. Lyon: IARC Press: 2004.

24. Bach PB, Kattan MW, Thornquist MD, Kris MG, Tate RC, Barnett MJ, Hsieh LJ, Begg CB. Variations in lung cancer risk among smokers. $J$ Natl Cancer Inst 2003;95:470-8. 
25. Janssen-Heijnen ML, Coebergh JW. The changing epidemiology of lung cancer in Europe. Lung Cancer 2003;41:245-58.

26. Alberg AJ, Brock MV, Samet JM. Epidemiology of lung cancer: looking to the future. J Clin Oncol 2005;23:3175-85.

27. Thomas L, Doyle A, Edelman J. Lung cancer in women: emerging differences in epidemiology, biology and therapy. Chest 2005;128:370-81.

28. Lortet-Tieulent J, Soerjomataram I, Ferlay J, Rutherford M, Weiderpass E, Bray F. International trends in lung cancer incidence by histological subtype: adenocarcinoma stabilizing in men but still increasing in women. Lung Cancer 2014;84:13-22.

29. Suda K, Tomizawa K, Mizuuchi H, Ito S, Kitahara H, Shimamatsu S, Kohno M, Yoshida T, Okamoto T, Maehara Y, Yatabe Y, Mitsudomi T. Genetic and prognostic differences of non-small cell lung cancer between elderly patients and younger counterparts. Aging Dis 2012;3:438-43.

30. Zhang Y, Sun Y, Pan Y, Li C, Shen L, Li Y, Luo X, Ye T, Wang R, Hu H, Li H, Wang L, Pao W, Chen H. Frequency of driver mutations in lung adenocarcinoma from female never-smokers varies with histologic subtypes and age at diagnosis. Clin Cancer Res 2012;18:1947-53.

31. Regina Gironés Sarrió, María Dolores Torregrosa, Pedro López, José Gómez-Codina, Rafael Rosell. Smoking habits in elderly lung cancer patients: still no changes in epidemiology? A single-center experience. Clin Transl Oncol 2010;12:686-91.

32. Meoni G, Cecere FL, Lucherini E, Di Costanzo F. Medical treatment of advanced non-small cell lung cancer in elderly patients: a review of the role of chemotherapy and targeted agents. $J$ Geriatr Oncol 2013;4:282-90.

33. Maione P, Rossi A, Sacco PC, Bareschino MA, Schettino C, Ferrara
ML, Falanga M, Ambrosio R, Gridelli C. Treating advanced non-small cell lung cancer in the elderly. Ther Adv Med Oncol 2010;2:251-60.

34. Gironés R, Torregrosa D, Gómez-Codina J, Maestu I, Tenias JM, Rosell R. Prognostic impact of comorbidity in elderly lung cancer patients: use and comparison of two scores. Lung Cancer 2011;72:108-13.

35. Regina Gironés, Dolores Torregrosa, Inma Maestu, José GómezCodina, Jose M. Tenias, Rafael Rosell Costa . Comprehensive Geriatric Assessment (CGA) of elderly lung cancer patients: a singlecenter experience. J Geriatr Oncol 2012;3:98-103.

36. Froesch P, Martucci F, Györik S, Dutly AE, Cafarotti S. Management of non-small cell lung cancer in the elderly. Eur J Intern Med 2014;25:888-94.

37. Ramalingam SS, Dahlberg SE, Langer CJ, Gray R, Belani CP, Brahmer JR, Sandler AB, Schiller JH, Johnson DH; Eastern Cooperative Oncology Group. Eastern Cooperative Oncology Group. Outcomes for elderly, advanced-stage non small-cell lung cancer patients treated with bevacizumab in combination with carboplatin and paclitaxel: analysis of Eastern Cooperative Oncology Group Trial 4599. J Clin Oncol 2008;26:60-5.

38. Alexa T, Lavinia A, Luca A, Miron L, Alexa ID. Incidence of chemotherapy discontinuation and characteristics of elderly patients with non-small cell lung cancer treated with platinum-based doublets. Contemp Oncol (Pozn) 2014;18:340-3.

39. Gironés R, Torregrosa D, Gómez-Codina J, Maestu I, Tenias JM, Rosell R. Lung cancer chemotherapy decisions in older patients: the role of patient preference and interactions with physicians. Clin Transl Oncol 2012;14:183-9. 